\title{
Influence of the addition of carbon fibers on the properties of hydraulic lime mortars: comparison with glass and basalt fibers
}

\author{
A. Bustos ${ }^{\mathrm{a}} \bowtie$, E. Moreno ${ }^{\mathrm{b}}$, F. González ${ }^{\mathrm{a}}$, A. Cobo $^{\mathrm{a}}$ \\ a. Department of Architectural Constructions and their Control, School of Building Construction, \\ Universidad Politécnica de Madrid, (Madrid, Spain) \\ b. Architectural Construction and Technology Department, School of Architecture, \\ Universidad Politécnica de Madrid, (Madrid, Spain) \\ $\triangle$ arturo.bustos.garcia@gmail.com
}

Received 5 January 2020

Accepted 3 April 2020

Available on line 27 August 2020

\begin{abstract}
In recent years, the use of hydraulic lime in conservation and restoration of historic buildings has increased due to the pathological processes involved in the use of Portland cement. This investigation determines the properties of hydraulic lime mortars with added carbon fibers for their possible use in restoration of architectural heritage. The results obtained are compared with mortars to which glass and basalt fibers have been added. The results show that the fibers affect significantly the behaviour of the mortar. Although the fibers have a negative impact in the workability and increase the air void content, they improve significantly the mechanical strengths. Although no relevant differences have been found in the pre-cracking behaviour, it has been proven that the fibers avoid a fragile behaviour of the mortar, showing a better post-cracking behaviour. Mortars with carbon fibers are the ones that show the best performance, increasing the toughness up to $12080 \%$ over the reference mortars.
\end{abstract}

KEYWORDS: Mortar; Hydraulic lime; Fibre reinforcement; Mechanical properties; Characterization.

Citation/Citar como: Bustos, A.; Moreno, E.; González, F.; Cobo, A. (2020) Influence of the addition of carbon fibers on the properties of hydraulic lime mortars: comparison with glass and basalt fibers. Mater. Construcc. 70 [340], e229 https://doi.org/10.3989/mc.2020.00120

RESUMEN: Influencia de la adición de fibras de carbon en las propiedades de los morteros de cal hidráulica: comparación con fibras de vidrio y basalto. En los últimos años, se ha incrementado el uso de cal hidráulica en trabajos de conservación y restauración de edificios históricos debido a los procesos patológicos involucrados en el uso de cemento Portland. En esta investigación se determinan las propiedades de los morteros de cal hidráulica con adición de fibras de carbono para su posible uso en restauración del patrimonio arquitectónico. Se comparan los resultados obtenidos con morteros a los que se les han añadido fibras de vidrio y basalto. Los resultados muestran que las fibras afectan significativamente al comportamiento del mortero, mejorando significativamente las resistencias mecánicas. Aunque no se han encontrado diferencias relevantes en el comportamiento previo al agrietamiento, se ha demostrado que las fibras evitan una rotura frágil del mortero, mostrando un mejor comportamiento posterior al agrietamiento. Los morteros con fibras de carbono son los presentan un mejor rendimiento, aumentando la tenacidad hasta un $12080 \%$ sobre los morteros de referencia.

PALABRAS CLAVE: Mortero; Cal hidráulica; Refuerzo de fibras; Propiedades mecánicas; Caracterización.

ORCID ID: A. Bustos (https://orcid.org/0000-0003-1225-3972); E. Moreno (https://orcid.org/0000-0001-6625-7093); F. González (https://orcid.org/0000-0002-9841-2462); A. Cobo (https://orcid.org/0000-0001-8270-7752)

Copyright: (C) 2020 CSIC. This is an open-access article distributed under the terms of the Creative Commons Attribution 4.0 International (CC BY 4.0) License. 


\section{INTRODUCTION}

Due to its excellent physical and mechanical properties, Portland cement is currently the most widely used binder in the manufacturing of construction mortars. However, its use in restoration works and the conservation of historical buildings, which was very common during the twentieth century, has been shown to be counterproductive due to the pathological processes which develop $(1,2)$. This incompatibility derives from its high mechanical strength in contrast to the base material, from the formation, due to the migration of alkaline ions, of a large quantity of soluble salts, the crystallization and subsequent increase in volume of which causes tensions and efflorescence, and from excessive water retention due to the low permeability of those mortars (3).

For this reason, the use of hydraulic lime has increased in projects involving buildings which form part of a region's historical heritage $(4,5)$. It may be said that hydraulic lime mortars represent a link between those using Portland cement and mortars dating from before the nineteenth century, displaying greater physical, chemical and mechanical compatibility with the materials normally used in these constructions (6).

The main disadvantage of hydraulic lime mortars is their high plastic shrinkage together with low mechanical strength and relatively fragile behavior when subjected to mechanical loads. Their limited deformation capacity and ability to absorb energy constitute a problem in certain situations, such as, for example, in the event of earthquakes, which may result in the detachment of fragments of mortar coating, putting human safety at risk.

This issue, widely studied in cement-based materials, can be overcome by incorporating glass fibers (7-9), basalt fibers (8-11) and carbon fibers (12-14) in the matrix. However, the behavior of hydraulic lime mortars with added fibers has been studied significantly less, indeed it was only possible to find a few albeit interesting references. Lucolano et al. (15) published that the addition of glass and basalt fibers improved the toughness and post-cracking behavior of hydraulic lime mortars. Santarelli et al. (16) reported an improvement in compressive and flexural strengths, as well as in the post-cracking behavior of hydraulic lime mortars featuring different types of basalt fiber. No references of the use of carbon fibers in hydraulic lime mortars have been found.

Consequently, obtaining hydraulic lime mortars with more ductile behavior and improved mechanical strength which can be used in historical buildings as an alternative to cement mortars implies attaining greater compatibility with the base materials used in old factories and, furthermore, providing a greater guarantee of the safety of these constructions.
In addition, from all these studies, it is possible to conclude that the fibers have a tendency to flocculation and therefore the amount of fiber that can be incorporated into the mixture is limited by the formation of "balls" (tangled fibers), which negatively affect their working capacity (17); and that the amount of fiber added varies by up to $10 \%$ (16), but that the best results are obtained from mixtures containing less than $1.5 \%(12,14)$.

This research formalizes a study (not done until the moment) about the behavior of hydraulic lime mortars with carbon fibers added. In addition, its influence is studied in comparison with glass and basalt fibers and a mortar with mixed glass and carbon fibers. Four percentages of fibers have been used over the total volume of the mortar $(0.33 \%$, $0.66 \%, 1 \%$ and $1.33 \%$ ). Based on an analysis of the load-deflection curves obtained from the flexural and compression tests, the energy absorption capacity of the material has been quantified.

\section{EXPERIMENTAL PROCEDURE}

\subsection{Materials}

In order to carry out the experimental work, hydraulic lime mortars were manufactured using the following materials:

- Natural hydraulic lime NHL 5, in accordance with regulation EN 459-1 (18), from Saint-Astier

- By way of aggregate, river sand that is siliceous in nature. With a size in the granulometric range of $0-4 \mathrm{~mm}$

- Carbon fibers (Mapei), AR glass fibers (Fiber Eagle) and basalt fibers (Mapei)

- Drinking water

- Glenium Sky 604 by way of superplasticizer

The technical characteristics of the fibers are shown in Table 1, whilst Figure 1 displays the appearance of the aforementioned fibers.

In order to be able to assess the effect of the fibers, reference mortars were produced by mixing $490 \mathrm{~kg} / \mathrm{m}^{3}$ of hydraulic lime, $1,470 \mathrm{~kg} / \mathrm{m}^{3}$ of silica sand and 0.65 water/binder ratio. Based on the reference mortars, different mortar mixtures were manufactured, adding carbon (CF), mixed (50\% carbon and $50 \%$ glass fibers) (MF), glass (GF) and basalt (BF) fibers. The percentages added are $0.33 \%, 0.66 \%, 1 \%$ and $1.33 \%$ over the total mortar volume. Finally, with the aim of improving the workability of the mortars following the addition of fiber, $2 \mathrm{~kg} / \mathrm{m}^{3}$ of a water-reducing additive were added to the mixture. Due to increase of population in developing countries the need forlow-cost residential housing has increased considerably around the world $(1,2)$. 
Influence of the addition of carbon fibers on the properties of hydraulic lime mortars: comparison with glass and basalt fibers $\bullet 3$

TABLE 1. Size and physical and mechanical properties of the materials.

\begin{tabular}{lccc}
\hline & Carbon fibers $(\mathbf{C F})$ & Glass fibers (GF) & Basalt fibers (BF) \\
\hline Length $(\mathrm{mm})$ & 12 & 12 & 12 \\
Density $\left(\mathrm{g} / \mathrm{cm}^{3}\right)$ & 1.79 & 2.68 & 2.75 \\
Elastic modulus $(\mathrm{GPa})$ & 230 & 72 & 91 \\
Tensile strength $(\mathrm{GPa})$ & $4.2-4.5$ & $1-1.7$ & $3.8-4.1$ \\
Elongation at break $(\%)$ & 2.1 & 4.3 & 3.1 \\
Specific elastic modulus $\left(\mathrm{GPa} / \mathrm{cm}^{3}\right)$ & 1 & 30 & 31.78 \\
\hline
\end{tabular}
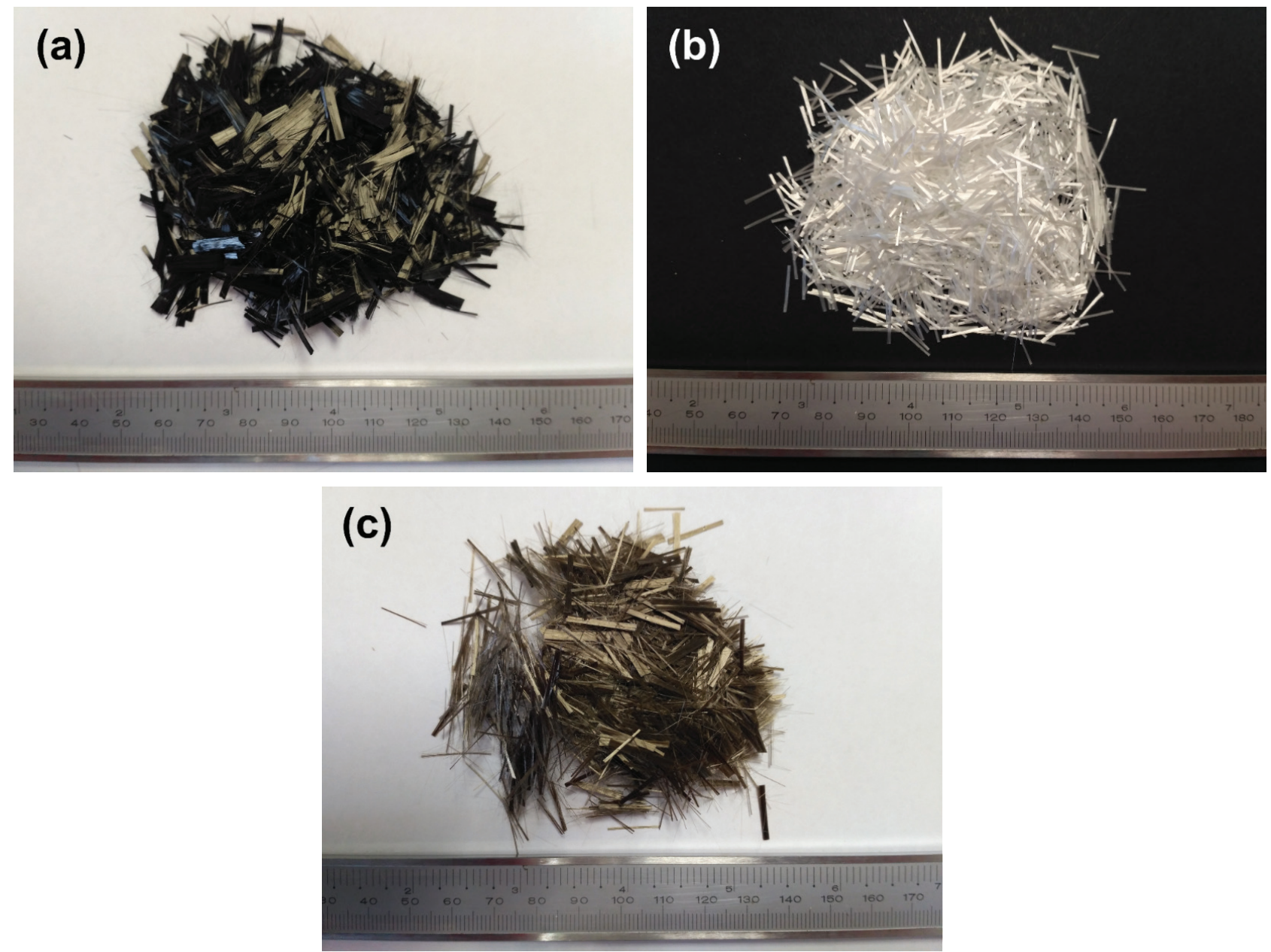

Figure 1. Appearance of the fibers used (a) carbon fibers (b) glass fibers (c) basalt fibers.

\subsection{Manufacturing and curing}

The mixing was performed in accordance with the procedure described in regulation EN 196-1 (19). To begin with, the water is mixed with the binder for 30 seconds on a slow speed, before gradually adding the sand for the following 30 seconds. The mixing is completed following the pattern of quick
(30 seconds) - stopped (90 seconds) - quick (60 seconds). In mortars with added fibers, taking into consideration the results obtained by Gao et. al. (20), the fibers are premixed with water for 60 seconds before adding the hydraulic lime and starting to mix. For each mortar tested, three prismatic test pieces were manufactured $\left(40 \times 40 \times 160 \mathrm{~mm}^{3}\right)$ and wrapped in polyethylene film for the first few hours in order 
to delay evaporation. The curing process was carried out in a humidity chamber at a temperature of $20^{\circ} \mathrm{C}$ and relative humidity of $95 \%$ for 28 days, according to standard EN 459-2 (21).

\subsection{Experimental techniques}

The physical properties; slump, density in a fresh and hardened state and trapped air content; were determined following the criteria set out in regulations EN 1015-3 (22), EN 1015-6 (23), EN 1015-10 (24) and EN 1015-7 (25), respectively.

The mechanical characterization of mortars was carried out in accordance with regulation EN 1015-11 (26). In order to perform the flexural strength testing, Ibertest model MIB-60/AM equipment was used featuring deflection control, a $100 \mathrm{~mm}$ separation between supports and a load speed of $0.4 \mathrm{~mm} / \mathrm{min}$. The tests to determine the compressive strength were performed using the fragments produced during flexural strength testing, with the same equipment and a deflection speed of $1 \mathrm{~mm} / \mathrm{min}$.

The toughness was obtained by calculating the area below the load-deflection curve up to a variable deflection, $\bar{\delta}$, as shown in the following Equation [1]:

$$
T_{\bar{\delta}}=\int_{0}^{\bar{\delta}} P \delta \mathrm{d} \delta
$$

As ASTM C1609 (27) recommends, the flexural toughness evaluation indexes are: the load at the first crack, the maximum load, the residual load and the area below the curve up to a deflection of $\mathrm{L} / 150$ ( $\mathrm{L}$ being the distance between supports). In this study, the indexes used to evaluate the flexural toughness of hydraulic lime mortars included the area below the curve up to breakage $\left(\mathrm{T}_{\mathrm{p}}\right)$, up to a deflection of $\mathrm{L} / 600\left(\mathrm{~T}_{\mathrm{L} / 600}\right)$, up to a deflection of $\mathrm{L} / 150\left(\mathrm{~T}_{\mathrm{L} / 150}\right)$ and up to collapse $\left(\mathrm{T}_{\mathrm{u}}\right)$. The maximum load $\left(\mathrm{P}_{\mathrm{p}}\right)$ and residual loads $\mathrm{P}_{\mathrm{L} / 600}, \mathrm{P}_{\mathrm{L} / 150}$ and $\mathrm{P}_{\mathrm{u}}(28,29)$, were also calculated.

The compressive toughness was determined by adapting the procedure set out in UNE 83508 (30). The area below the load-deflection curve was calculated up to breakage $\left(\mathrm{T}_{\mathrm{cp}}\right)$, up to a deflection of $1.125 \mathrm{~mm}\left(\mathrm{~T}_{\mathrm{c} 1.125}\right)$ and up to a deflection of $2.250 \mathrm{~mm}$ $\left(\mathrm{T}_{\mathrm{c} 2.250}\right)$. The maximum compression load $\left(\mathrm{P}_{\mathrm{cp}}\right)$ and residual loads $\mathrm{P}_{\mathrm{c} 1.125}$ and $\mathrm{P}_{\mathrm{c} 2.250}$ (31) were also calculated.

The microstructural characterization and morphology of the fracture surfaces of the hardened samples was carried out using a scanning electron microscope (SEM Jeol JSM-820). All samples were coated using gold sputtering before testing.
TABle 2. Physical properties of the mortar mixtures.

\begin{tabular}{lcccc}
\hline $\begin{array}{l}\text { Mortar } \\
\text { mixtures }\end{array}$ & $\begin{array}{c}\text { Slump } \\
\text { cm }\end{array}$ & $\begin{array}{c}\text { Air void } \\
\text { content } \\
(\%)\end{array}$ & $\begin{array}{c}\text { Density. } \\
\text { Fresh Mortar } \\
\left(\mathbf{k g} / \mathbf{m}^{3}\right)\end{array}$ & $\begin{array}{c}\text { Density. } \\
\text { Hardened } \\
\text { Mortar }\left(\mathbf{k g} / \mathbf{m}^{3}\right)\end{array}$ \\
\hline R & 190 & 3.1 & 2110 & 1970 \\
CF-0.33 & 150 & 4.1 & 2100 & 1930 \\
CF-0.66 & 150 & 5.3 & 2050 & 1900 \\
CF-1 & 140 & 6.0 & 2000 & 1860 \\
CF-1.33 & 130 & 6.9 & 1950 & 1830 \\
MF-0.33 & 160 & 4.0 & 2080 & 1880 \\
MF-0.66 & 160 & 5.3 & 2040 & 1860 \\
MF-1 & 140 & 6.5 & 2020 & 1820 \\
MF-1.33 & 140 & 7.3 & 1980 & 1790 \\
GF-0.33 & 160 & 3.5 & 2100 & 1920 \\
GF-0.66 & 150 & 4.7 & 2080 & 1890 \\
GF-1 & 140 & 6.3 & 2020 & 1850 \\
GF-1.33 & 140 & 7.5 & 1980 & 1820 \\
BF-0.33 & 160 & 4.2 & 2110 & 1960 \\
BF-0.66 & 150 & 5.1 & 2030 & 1920 \\
BF-1 & 140 & 6.1 & 2020 & 1900 \\
BF-1.33 & 140 & 6.9 & 2000 & 1860 \\
\hline & & & &
\end{tabular}

\section{RESULTS}

\subsection{Physical properties}

The physical properties of the mortars are shown in Table 2. The gradual increase in the amount of fibers added implies a drop in slump, which has a negative impact on the workability of the mortars (32). This effect is common to all of the fibers, not showing significant differences. It is due to the formation of a mesh-like structure which stems from the fact that the distribution of the fibers restricts the segregation of the mixture. This, together with the greater amount of binder required in order to coat the fibers (due to their high specific surface) results in the increased viscosity of the mixture (33). As a result, the formation of "groups" or "tangled fibers" (Figure 2) is observed, having a negative effect on the workability.

Furthermore, the increased fiber amount implies a drop in the mortar density due to the increase in trapped air, resulting in mortars which are less compact. This phenomenon derives from an interruption in the continuity of the material's microstructure, as a result of including fibers in a homogeneous body.

\subsection{Flexural and compressive strength}

The average flexural and compressive strengths for the different hydraulic lime mortars are set out in Table 3. The strengths' increase by the addition 


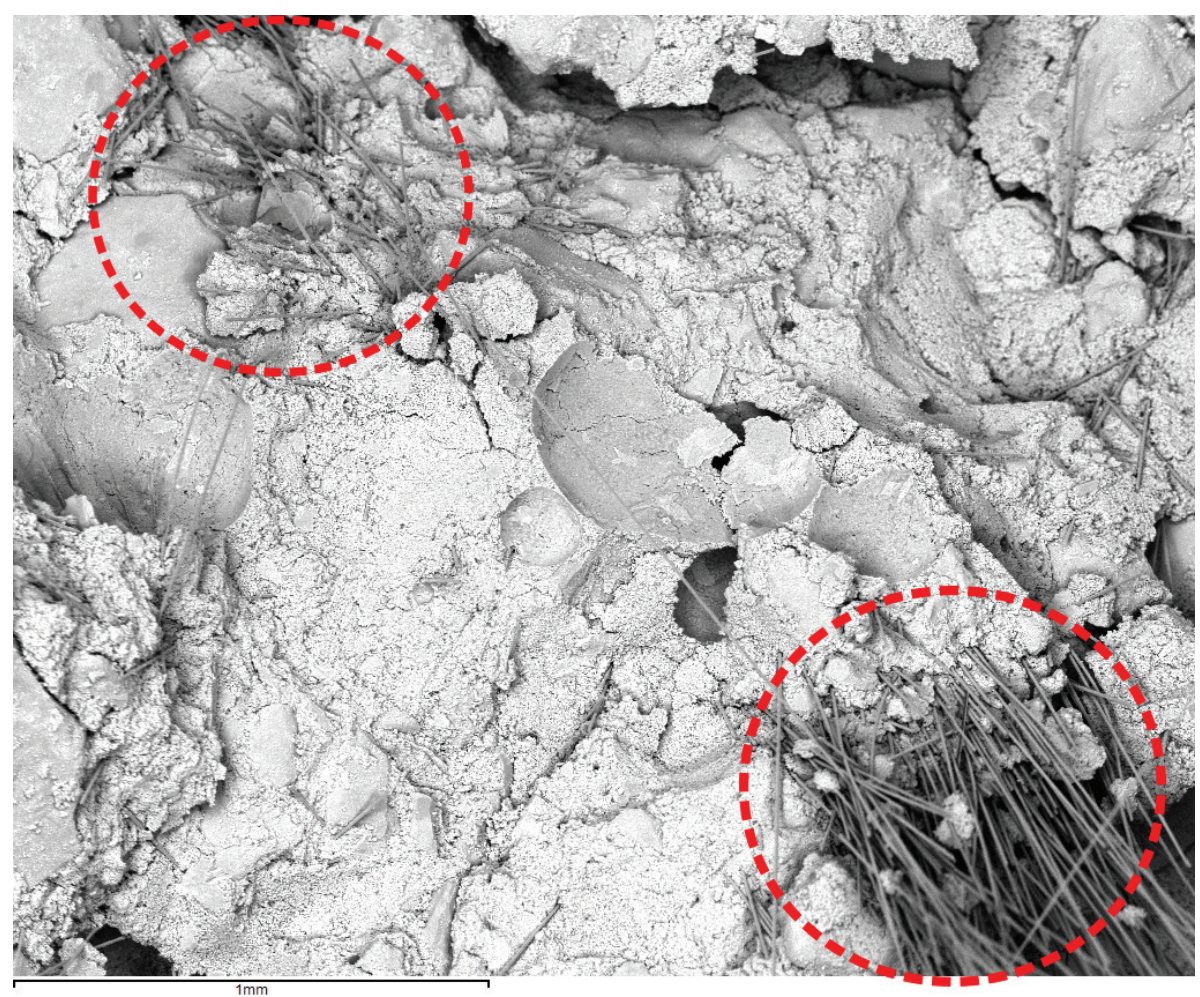

FIGURE 2. Image of backscattered electrons. BSE at 250 magnifications. Formation of fiber clusters.

TABLE 3. Mechanical properties of the mortar mixtures.

\begin{tabular}{lllll}
\hline $\begin{array}{l}\text { Mortar } \\
\text { mixtures }\end{array}$ & \multicolumn{2}{c}{$\begin{array}{c}\text { Flexural } \\
\text { strength (MPa) }\end{array}$} & \multicolumn{2}{c}{$\begin{array}{c}\text { Compressive } \\
\text { strength (MPa) }\end{array}$} \\
\hline R & 0.74 & $(0.02)$ & 2.49 & $(0.17)$ \\
CF-0.33 & 0.96 & $(0.07)$ & 2.60 & $(0.22)$ \\
CF-0.66 & 1.18 & $(0.07)$ & 3.02 & $(0.15)$ \\
CF-1 & 1.47 & $(0.14)$ & 3.29 & $(0.17)$ \\
CF-1.33 & 1.38 & $(0.11)$ & 3.32 & $(0.11)$ \\
MF-0.33 & 1.03 & $(0.11)$ & 3.00 & $(0.16)$ \\
MF-0.66 & 1.07 & $(0.16)$ & 3.11 & $(0.12)$ \\
MF-1 & 1.31 & $(0.05)$ & 3.65 & $(0.13)$ \\
MF-1.33 & 1.33 & $(0.10)$ & 3.61 & $(0.19)$ \\
GF-0.33 & 1.01 & $(0.06)$ & 2.98 & $(0.17)$ \\
GF-0.66 & 1.18 & $(0.07)$ & 3.30 & $(0.35)$ \\
GF-1 & 1.36 & $(0.14)$ & 3.78 & $(0.25)$ \\
GF-1.33 & 1.33 & $(0.15)$ & 3.81 & $(0.19)$ \\
BF-0.33 & 0.99 & $(0.05)$ & 2.72 & $(0.08)$ \\
BF-0.66 & 1.23 & $(0.04)$ & 3.29 & $(0.09)$ \\
BF-1 & 1.40 & $(0.08)$ & 3.60 & $(0.18)$ \\
BF-1.33 & 1.40 & $(0.13)$ & 3.44 & $(0.17)$ \\
\hline
\end{tabular}

of fibers can be seen in Figure 3. When compared with the reference mortars, the average values increase by $35 \%, 57 \%, 87 \%$ and $84 \%$, for addition percentages of $0.33 \%, 0.66 \%, 1 \%$ and $1.33 \%$ respectively (Figure 3.a). In a similar way, compressive strength increases when any type of fiber is added (Figure 3.b), averaging increases of 13\%, 28\%, 44\% and $42 \%$ compared with the reference values.

Regardless of the type of fiber added, the flexural and compressive strengths of the mortars increase with the addition of fibers up to $1 \%$. At higher contents, a resistances decrease takes place due to the difficulty of dispersing high amounts of fibers (20). Because the resistances variation depends on numerous factors (such as, the cementitious matrix, the nature of the aggregate and the type and length of the fibers), contradictory data has been found in the bibliography regarding the mechanical resistances $(15,16)$. Therefore, the results have to be compared with similar materials.

With regards to the type of fiber, observing the standard deviation of each of the experimental mortars, there are no significant differences between the different fibers, and no substantial improvement is found when carbon fibers are added.

\subsection{Flexural toughness indexes}

The flexural behavior of hydraulic lime mortars can be divided into four stages, as shown in Figure 4. Up until reaching a load of between $0.35 \mathrm{kN}$ and $0.40 \mathrm{kN}$, the behavior is linear (stage I). After this 
(a)

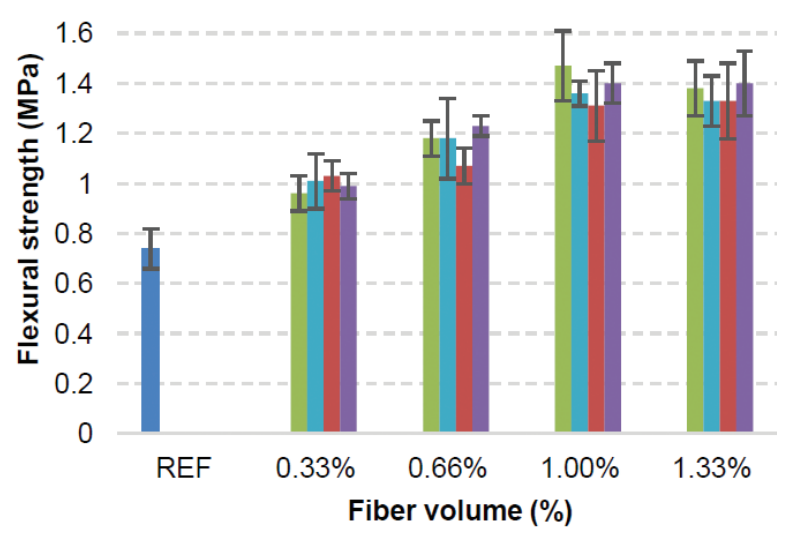

$\square \mathrm{REF} \square \mathrm{CF} \square \mathrm{MF} \square \mathrm{GF} \square \mathrm{BF}$ (b)

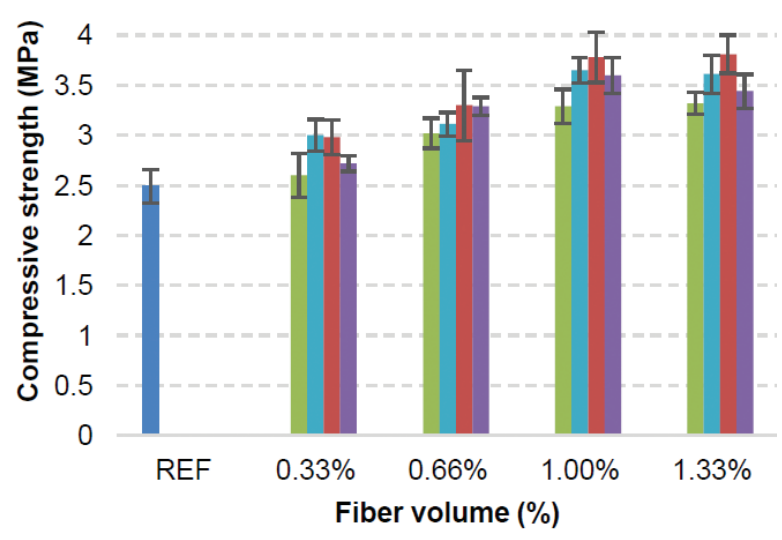

$\square \mathrm{REF} \backsim \mathrm{CF} \square \mathrm{MF} \square \mathrm{GF} \square \mathrm{BF}$

FIgURE 3. Strengths of the hydraulic lime mortars: (a) flexural strength; (b) compressive strength.

(a)

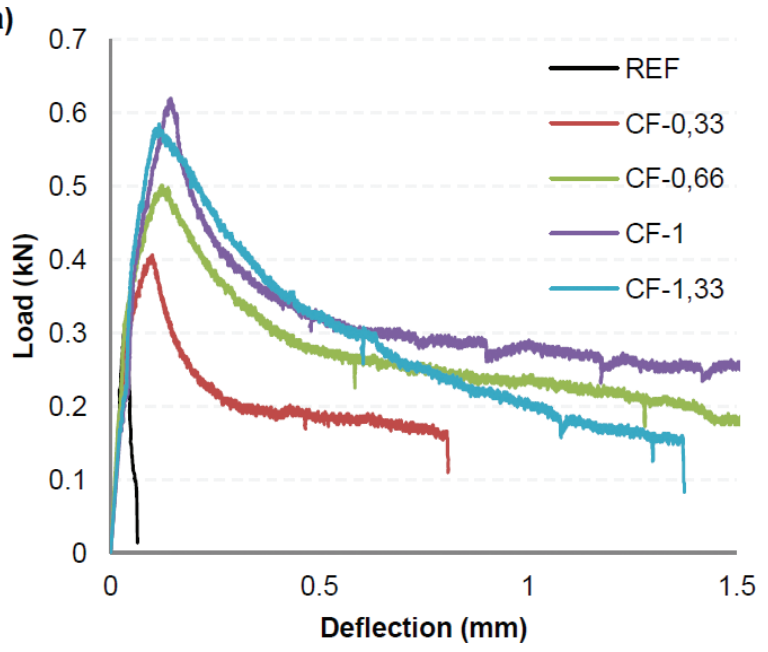

(c)

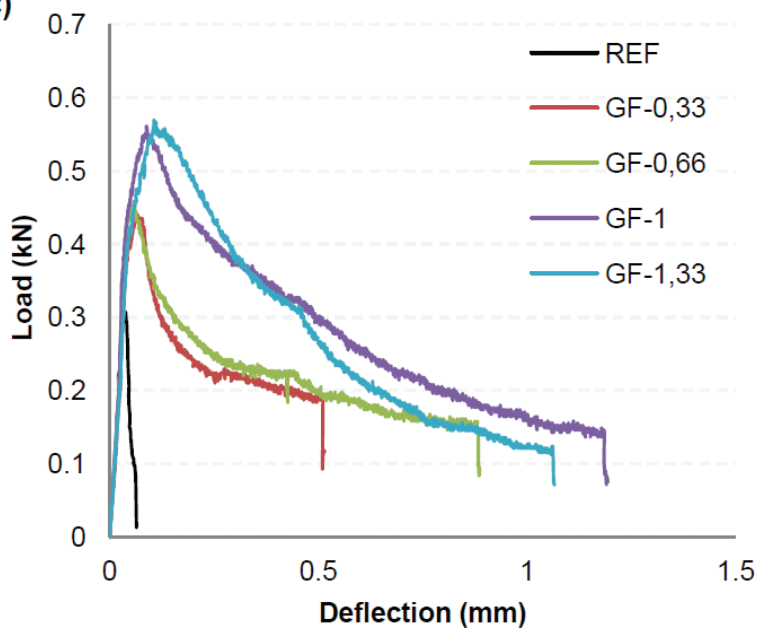

(b)

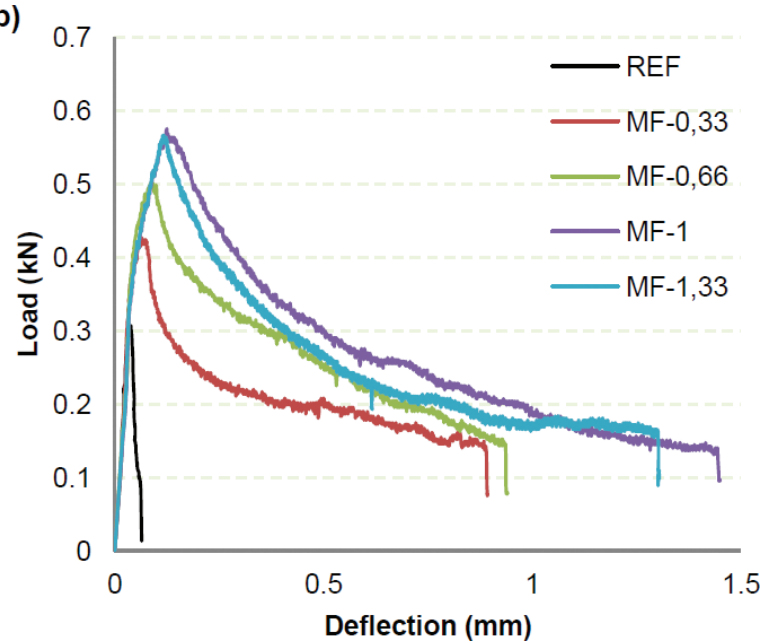

(d)

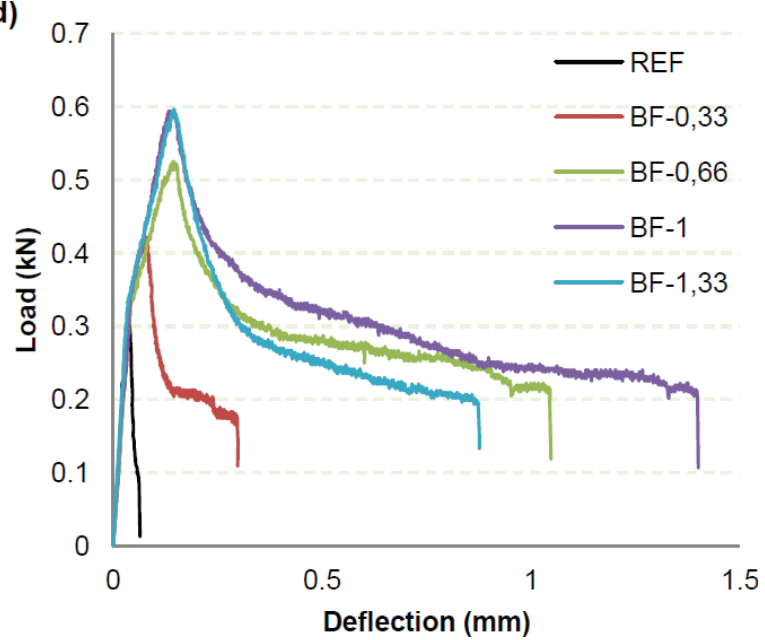

FIGURE 4. Flexural behavior of hydraulic lime mortars containing added fibers: (a) carbon fibers (b) mixed fibers (c) glass fibers (d) basalt fibers. 
point, the behavior is still noticeably linear but the gradient of the line is lower due to the lower rigidity of the test piece, caused by micro-cracking (stage II). Once the maximum load has been reached, the stitching effect between the fibers prevents brittle fractures, displaying improved post-cracking behavior compared to mortar mixes which do not contain added fibers (stages III and IV). In the third phase, the residual loads rapidly drop before stabilizing and slowly dropping until reaching collapse (stage IV). While, the mortar mixes which do not contain added fibers display brittle fractures, the toughness of the mortars with added fibers increases with the fiber content until this reaches $1 \%$, displaying lower values for a fiber content of $1.33 \%$.

The parameters that quantify the toughness are shown in Table 4; the area below the curve up to breakage $\left(\mathrm{T}_{\mathrm{p}}\right)$, up to a deflection of $\mathrm{L} / 600\left(\mathrm{~T}_{\mathrm{L} / 600}\right)$, up to a deflection of $\mathrm{L} / 150\left(\mathrm{~T}_{\mathrm{L} / 150}\right)$ and up to collapse $\left(\mathrm{T}_{\mathrm{u}}\right)$; as well as the maximum load $\left(\mathrm{P}_{\mathrm{p}}\right)$ and residual loads $\mathrm{P}_{\mathrm{L} / 600}, \mathrm{P}_{\mathrm{L} / 150}$ and $\mathrm{P}_{\mathrm{u}}$. The rise in the values of these parameters as the percentage of fiber addition increases highlights the increased ductility of these mortar mixes, irrespective of the fiber type added.

In comparison to the reference mortar, the addition of $0.33 \%, 0.66 \%, 1 \%$ or $1.33 \%$ of carbon, mixed, glass and basalt fibers, implies an increase in values $\mathrm{T}_{\mathrm{p}}, \mathrm{T}_{\mathrm{L} / 150}$ and $\mathrm{T}_{\mathrm{u}}$ of $204 \%, 1029 \%$ and $1883 \%$, of $409 \%, 2776 \%$ and $4348 \%$, of $566 \%, 3431 \%$ and
$7029 \%$ and of $562 \%, 3235 \%$ and $4516 \%$, respectively. The toughness increases to a greater extent when the fiber added is carbon fiber, obtaining $T_{p}$, $\mathrm{T}_{\mathrm{L} / 150}$ and $\mathrm{T}_{\mathrm{u}}$ values which are $683 \%, 3620 \%$ and $12070 \%$ higher than those for the reference mortars.

The evolution of the energy absorption values of the different mortars tested to a deflection of L/600 $\left(T_{L / 600}\right)$ and to the collapse $\left(T_{u}\right)$ is shown in Figure 5. As can be observed, the $\mathrm{T}_{\mathrm{L} / 600}$ and $\mathrm{T}_{\mathrm{u}}$ values increase with the addition of fibers, the optimum percentage being $1 \%$. The increase of the $\mathrm{T}_{\mathrm{L} / 600}$ values is very similar in all of the mortar mixes, irrespective of the type of fiber added, being between $40 \%$ and $55 \%$. This shows us the low influence of the type of fiber in the first phase of post-cracking fissuration. However, when the specimen is subjected to greater deformations, the influence of the fiber's nature increases. On average, mortars with carbon fibers show $\mathrm{T}_{\mathrm{L} / 150}$ and $\mathrm{T}_{\mathrm{u}}$ values a $7 \%$ and $63 \%$ higher to mortars containing a mixture of fibers, a $17 \%$ and $102 \%$ higher to mortars containing glass fibers and a $18 \%$ and $80 \%$ higher to mortars containing basalt fibers. These results show the best post-break behavior of mortars with carbon fibers.

This data highlights the improved behavior of mortar mixes containing added fibers. This improvement, already reported by other authors $(15,16)$, is due to the fact that the fibers, which are randomly placed in every direction throughout the mortar mixture, act as "bridges" or "hooks" between the

TABLE 4. Flexural toughness indexes of hydraulic lime mortars.

\begin{tabular}{|c|c|c|c|c|c|c|c|c|}
\hline & $P_{p}(k N)$ & $P_{\mathrm{L} / 600}(\mathrm{kN})$ & $\mathrm{P}_{\mathrm{L} / 150}(\mathrm{kN})$ & $P_{u}(k N)$ & $T_{p}(k N$ mm) & $\mathrm{T}_{\mathrm{L} / 600}(\mathrm{kN} \mathrm{mm})$ & $\mathrm{T}_{\mathrm{L} / 150}(\mathrm{kN} \mathrm{mm})$ & $T_{u}(\mathrm{kN} \mathrm{mm})$ \\
\hline $\mathrm{R}$ & 0.30 & & & & 0.0070 & & & \\
\hline CF-0.33 & 0.40 & 0.27 & 0.17 & 0.16 & 0.0270 & 0.0496 & 0.1489 & 0.1728 \\
\hline CF-0.66 & 0.50 & 0.15 & 0.26 & 0.16 & 0.0434 & 0.0634 & 0.2212 & 0.4878 \\
\hline CF-1 & 0.62 & 0.56 & 0.30 & 0.19 & 0.0548 & 0.0721 & 0.2604 & 0.8519 \\
\hline $\mathrm{CF}-1.3$ & 0.58 & 0.54 & 0.27 & 0.15 & 0.0461 & 0.0700 & 0.2562 & 0.3978 \\
\hline MF-0.33 & 0.42 & 0.26 & 0.17 & 0.13 & 0.0176 & 0.0503 & 0.1533 & 0.1883 \\
\hline MF-0.66 & 0.52 & 0.38 & 0.20 & 0.15 & 0.0307 & 0.0626 & 0.2049 & 0.2527 \\
\hline MF-1 & 0.58 & 0.54 & 0.26 & 0.14 & 0.0465 & 0.0704 & 0.2447 & 0.3887 \\
\hline MF-1.3 & 0.56 & 0.48 & 0.22 & 0.16 & 0.0437 & 0.0693 & 0.2253 & 0.3409 \\
\hline GF-0.33 & 0.43 & 0.26 & & 0.19 & 0.0181 & 0.0506 & & 0.1245 \\
\hline GF-0.66 & 0.45 & 0.29 & 0.17 & 0.15 & 0.0202 & 0.0544 & 0.1633 & 0.1977 \\
\hline GF-1 & 0.56 & 0.45 & 0.24 & 0.14 & 0.0328 & 0.0717 & 0.2381 & 0.3306 \\
\hline GF-1.3 & 0.57 & 0.53 & 0.19 & 0.11 & 0.0389 & 0.0716 & 0.2351 & 0.2932 \\
\hline BF-0.33 & 0.42 & 0.21 & & 0.17 & 0.0224 & 0.0442 & & 0.0697 \\
\hline BF-0.66 & 0.52 & 0.46 & 0.26 & 0.20 & 0.0482 & 0.0623 & 0.2158 & 0.3071 \\
\hline BF-1 & 0.59 & 0.53 & 0.30 & 0.20 & 0.0523 & 0.0688 & 0.2456 & 0.4250 \\
\hline BF-1.3 & 0.60 & 0.52 & 0.22 & 0.20 & 0.0566 & 0.0698 & 0.2174 & 0.2607 \\
\hline
\end{tabular}




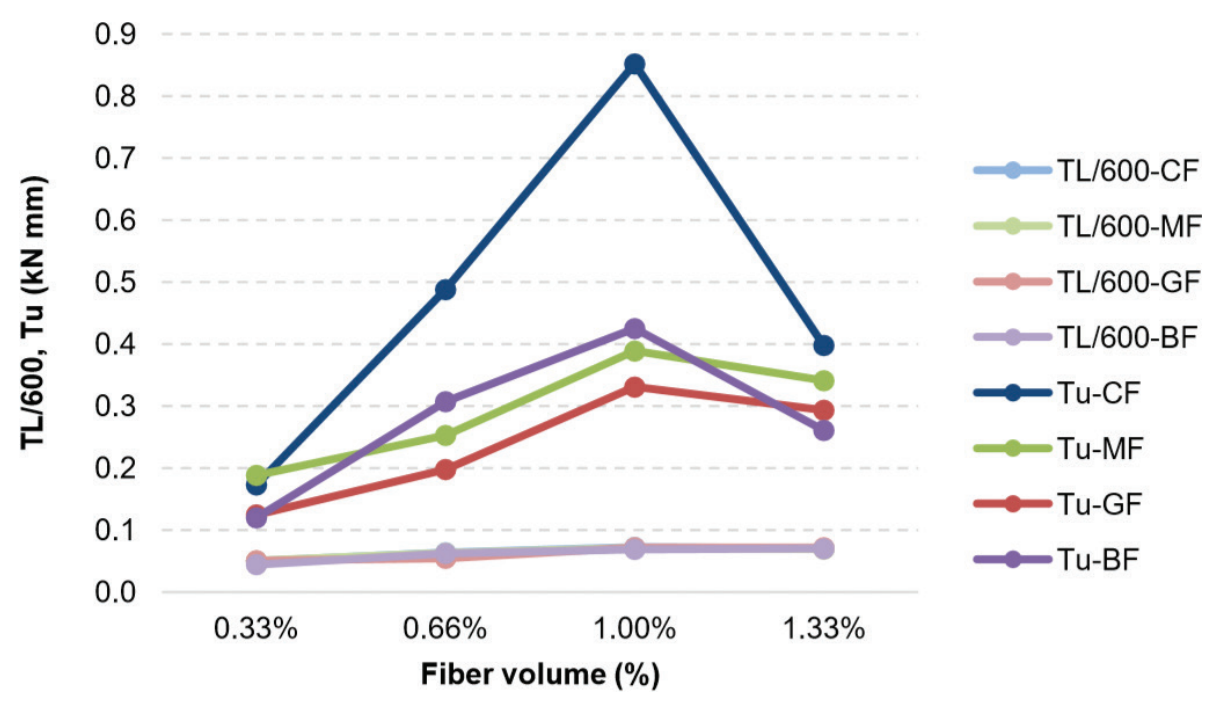

FIGURE 5. Evolution of energy absorption values on bending up to a deflection of L/600 (TL/600) and of collapse ( $\mathrm{Tu}$ ) for the different types of mortars containing fibers.

sides of a crack and are able to transmit the effort with highly variable angles depending on their position in relation to the cracking plane.

There are two effects which are useful for improving the post-cracking behavior of hydraulic lime mortars containing fibers: increasing the effort required for fracturing to begin and increasing the energy required for cracking to continue spreading. Both effects depend on the interaction between the fibers and the matrix. Micrographs (BSE at 1000 magnifications) of the fracture surfaces of hydraulic lime mortars with fibers $(1 \%)$ are shown in Figure 6. It can be observed how there is a certain amount of hydraulic lime attached to the surface of the fibers, which indicates good bonding between hydraulic lime matrix and the fibers and an effective load transfer mechanism.

Meanwhile, the absence of fiber breakage leads to the conclusion that the fault is caused by the extraction or slipping of the fibers, an effect which is known as 'pull-out'. The grooves formed when the fibers are extracted can be seen in Figure 7, confirming this trend. This separation mechanism was found in other studies using acrylic fibers (34), glass (35), basalt fibers (36), polypropylene fibers (37) and steel fibers (38).

\subsection{Compressive toughness indexes}

The compressive behavior of hydraulic lime mortars can be divided into four stages, as shown in Figure 8. Up until reaching a load of between $3.5 \mathrm{kN}$ and $4 \mathrm{kN}$, the behavior is linear (stage I). After this point, the linearity starts to disappear due to the lower rigidity caused by micro-cracking and it takes on a parabolic shape (stage II). Once the maximum load has been reached, the residual strengths fall, a greater or lesser deflection being required depending on the amount of fibers added (stage III). On compression, ductility increases with a fiber content of up to $1 \%$, a fiber content of $1.33 \%$ displaying similar or lower results.

The most representative results from analyzing the diagrams displaying load-deflection on compression are shown in Table 5. The area below the curve was calculated up to breakage $\left(\mathrm{T}_{\mathrm{cp}}\right)$, up to a deflection of $1.125 \mathrm{~mm}\left(\mathrm{~T}_{\mathrm{cl} 125}\right)$ and up to a deflection of $2.250 \mathrm{~mm}\left(\mathrm{~T}_{\mathrm{c} 2.250}\right)$. The maximum compression load $\left(\mathrm{P}_{\mathrm{cp}}\right)$ and residual loads $\mathrm{P}_{\mathrm{c} 1,125}$ and $\mathrm{P}_{\mathrm{c} 2,250}$ were also calculated.

In comparison with the reference mortar, the addition of $0.33 \%, 0.66 \%, 1 \%$ or $1.33 \%$ of carbon, mixed, glass and basalt fibers, represents an increase in the $\mathrm{T}_{\mathrm{cp}}, \mathrm{T}_{\mathrm{cl} 125}$ and $\mathrm{T}_{\mathrm{c} 2.250}$ values of $74 \%, 9 \%$ and $21 \%$, of $110 \%, 21 \%$ and $37 \%$, of $147 \%, 34 \%$ and $54 \%$ and of $154 \%, 32 \%$ and $51 \%$, respectively. When $1 \%$ carbon fibers is added, the toughness index, $\mathrm{T}_{\mathrm{cp}}$, $\mathrm{T}_{\mathrm{c} 1.125}$ and $\mathrm{T}_{\mathrm{c} 2.250}$, increase by $106 \%, 27 \%$ and $43 \%$ over the reference mortars.

The evolution of the compression energy absorption values of the different mortars tested to a deflection of $1,125 \mathrm{~mm}\left(\mathrm{~T}_{\mathrm{cl} 1,125}\right)$ and $2,250 \mathrm{~mm}\left(\mathrm{~T}_{\mathrm{c} 2,250}\right)$ is shown in Figure 9. The $T_{c 1.125}$ and $T_{c 2.250}$ values increase with the addition of fibers, the optimum percentage being $1 \%$. This increase is very similar in all of the mortar mixes, irrespective of the type of fiber added. However, the best results are obtained when glass fibers are added, with $\mathrm{T}_{\mathrm{cl} .125}$ and $\mathrm{T}_{\mathrm{c} 2.250}$ values a $10 \%$ and $11 \%$ higher to those obtained in mortars with carbon fibers, a $4 \%$ and $5 \%$ higher to those containing mixed fibers, and a $7 \%$ and $7 \%$ higher to those containing basalt fibers. 

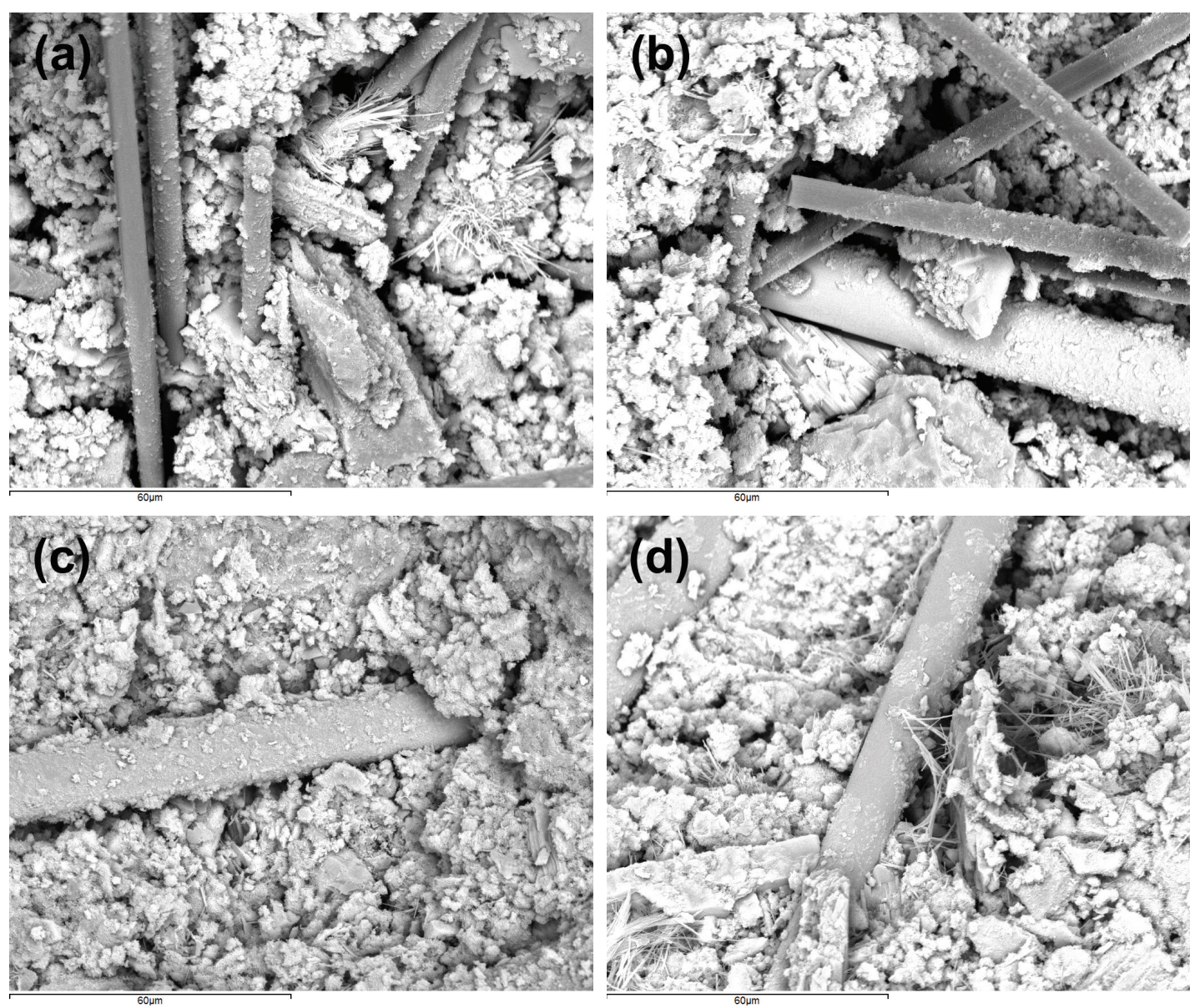

FIgURE 6. BSE at 1000 magnifications of hydraulic lime mortars: (a) carbon fibers (b) mixed fibers (c) glass fibers (d) basalt fibers.

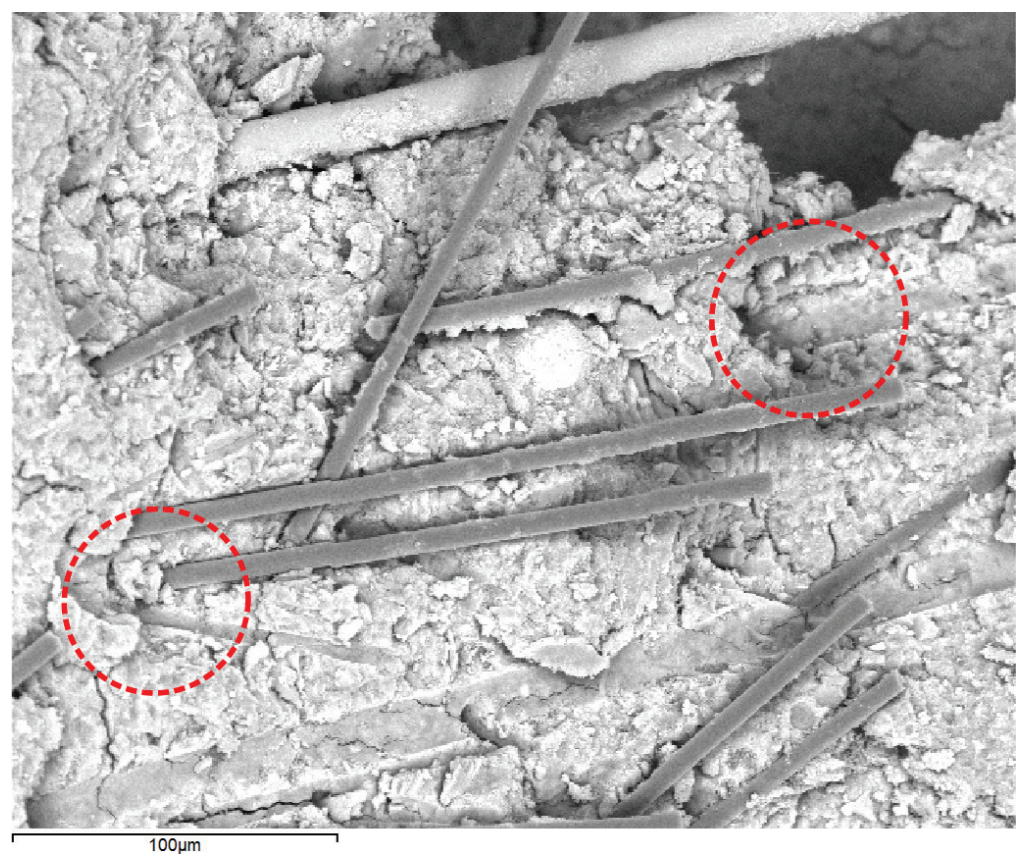

FIGURE 7. BSE at 400 magnifications of hydraulic lime mortars. Example of pull-out in hydraulic lime mortar containing mixed fibers. 
$10 \cdot$ A. Bustos et al.

(a)

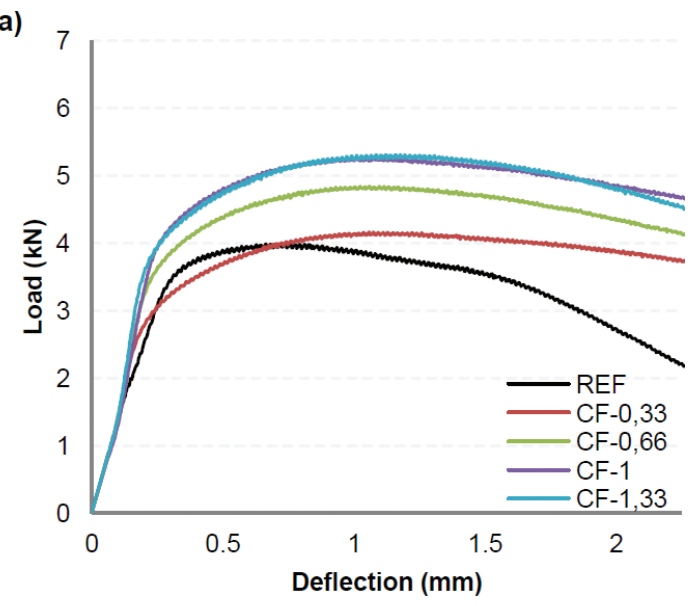

(c)

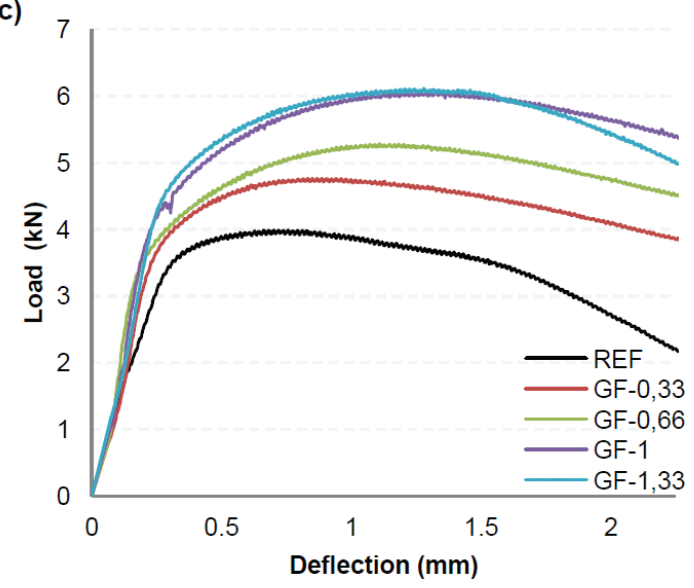

(b)

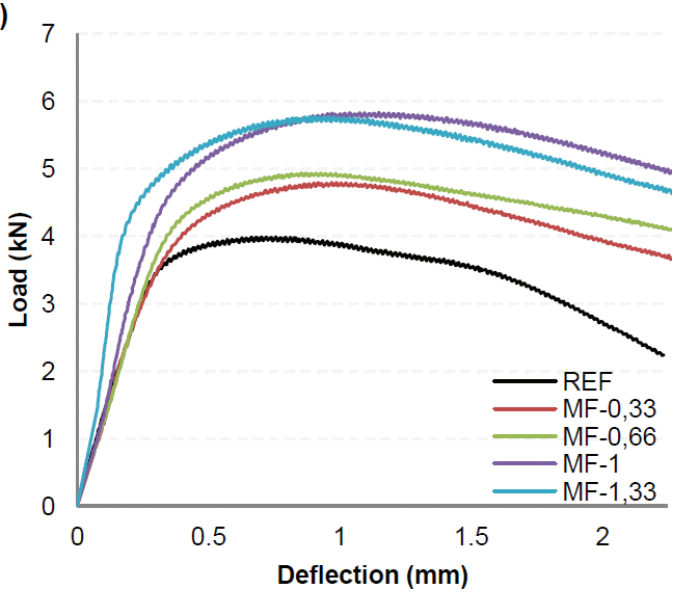

(d)

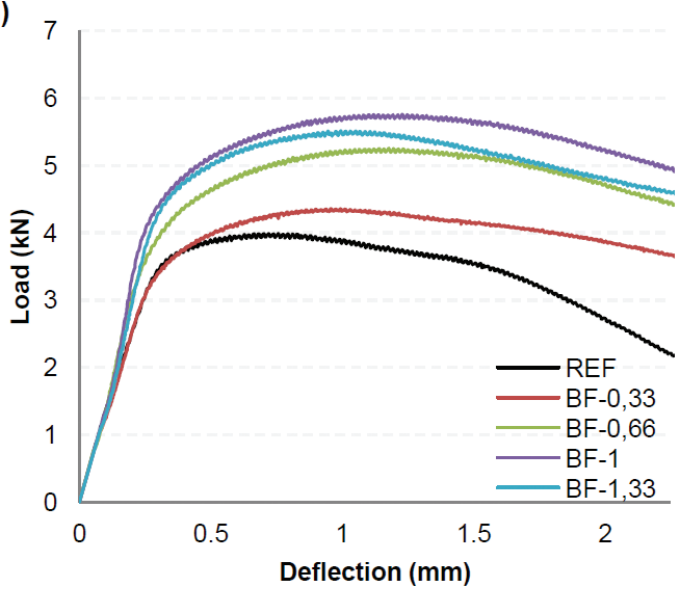

FiguRE 8. Compressive behavior of hydraulic lime mortars containing added fibers: (a) carbon fibers (b) mixed fibers (c) glass fibers (d) basalt fibers.

TABle 5. Compressive toughness indexes for hydraulic lime mortars.

\begin{tabular}{lcccccc}
\hline & $\mathbf{P}_{\mathbf{c p}}(\mathbf{k N})$ & $\mathbf{P}_{\mathbf{c 1 . 1 2 5}}(\mathbf{k N})$ & $\mathbf{P}_{\mathbf{c} 2.250}(\mathbf{k N})$ & $\mathbf{T}_{\mathbf{c p}}(\mathbf{k N ~} \mathbf{~ m m})$ & $\mathbf{T}_{\mathbf{c l} . \mathbf{1 2 5}}(\mathbf{k N} \mathbf{~ m m})$ & $\mathbf{T}_{\mathbf{c} 2.250}(\mathbf{k N ~} \mathbf{~ m m})$ \\
\hline R & 3.98 & 3.75 & 2.18 & 1.95 & 3.75 & 7.28 \\
CF-0.33 & 4.15 & 4.14 & 3.73 & 3.73 & 3.79 & 8.27 \\
CF-0.66 & 4.82 & 4.81 & 4.13 & 3.96 & 4.43 & 9.55 \\
CF-1 & 5.25 & 5.25 & 4.67 & 4.02 & 4.78 & 10.43 \\
CF-1.3 & 5.30 & 5.28 & 4.59 & 4.79 & 4.77 & 10.32 \\
MF-0.33 & 4.73 & 4.72 & 3.70 & 3.13 & 4.25 & 8.94 \\
MF-0.66 & 4.89 & 4.84 & 4.10 & 3.49 & 4.35 & 9.43 \\
MF-1 & 5.82 & 5.79 & 4.94 & 4.84 & 5.18 & 11.32 \\
MF-1.3 & 5.76 & 5.68 & 4.68 & 4.63 & 5.09 & 11.17 \\
GF-0.33 & 4.74 & 4.72 & 3.84 & 3.30 & 4.42 & 9.29 \\
GF-0.66 & 5.27 & 5.25 & 4.50 & 4.68 & 4.77 & 10.35 \\
GF-1 & 6.01 & 5.99 & 5.40 & 5.76 & 5.24 & 11.66 \\
GF-1.3 & 6.06 & 6.05 & 5.08 & 5.24 & 5.15 & 11.65 \\
BF-0.33 & 4.35 & 4.33 & 3.67 & 3.39 & 3.88 & 8.43 \\
BF-0.66 & 5.20 & 5.19 & 4.46 & 4.26 & 4.66 & 10.10 \\
BF-1 & 5.74 & 5.74 & 4.97 & 4.67 & 4.97 & 11.12 \\
BF-1.3 & 5.48 & 5.45 & 4.59 & 5.13 & 4.86 & 10.55 \\
\hline
\end{tabular}




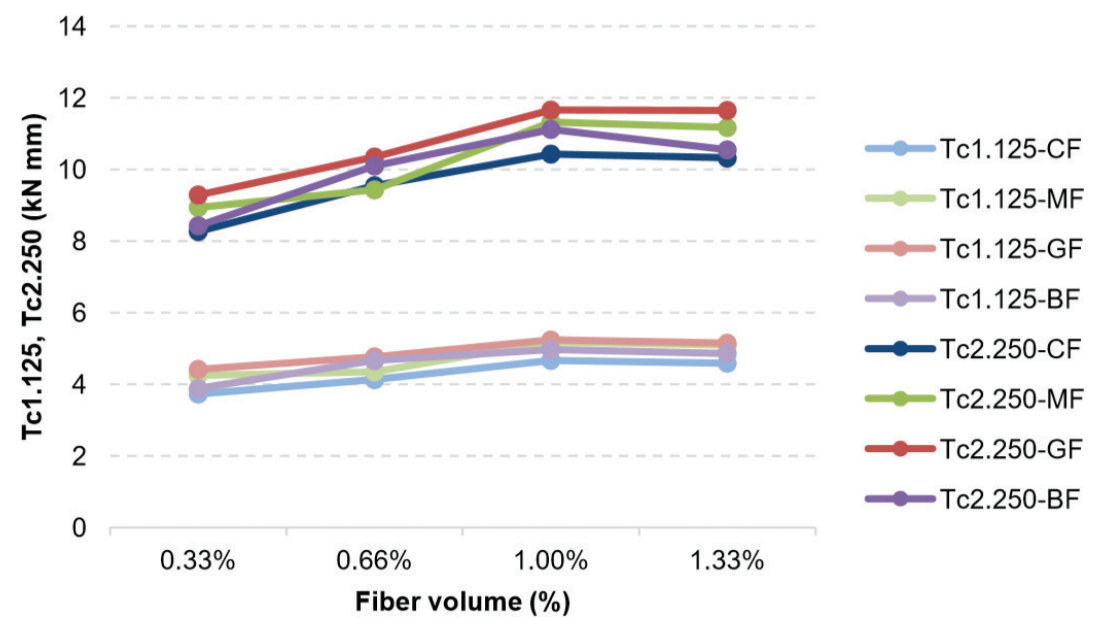

FIGURE 9. Evolution of the energy absorption values on compression up to a deflection of $1.125 \mathrm{~mm}(\mathrm{Tc} 1.125)$ and of $2.250 \mathrm{~mm}$ (Tc2.250) for the different types of mortar containing fibers.

\section{CONCLUSIONS}

This research studies the physical and mechanical properties of hydraulic lime mortars with addition of carbon fibers, analyzing its influence in comparison with mortars with glass and basalt fibers.

The results confirm that the fibers significantly affect mortar behavior. Having obtained and examined the results, the following conclusions can be reached:

- The addition of fibers to mortar mixes implies a loss of workability and an increase in the amount of trapped air, resulting in less compact mortars.

- The flexural and compressive strength values gradually rise with the increase in fiber content until this reaches $1 \%$ at which point the best results are obtained. Although mortars with carbon fibers have better a mechanical behaviour, there are no significant differences when other types of fibers are added.

- Mortars with fibers addition have a better postcracking behaviour, regardless of the type of fiber added. Mortars with carbon fibers are the ones that show the best performance with an increase in toughness up to $12,080 \%$ over the reference mortars.

- The toughness indexes, $\mathrm{T}_{\mathrm{L} / 150}$ and $\mathrm{T}_{\mathrm{u}}$, of hydraulic lime mortars with carbon fibers are a $7 \%$ and $63 \%$ higher to mortars with mixed of fibers, a $17 \%$ and $102 \%$ higher to mortars with glass fibers and a $18 \%$ and $80 \%$ higher to mortars with basalt fibers.

- The SEM images show good bonding between the hydraulic lime matrix and the fibers without obvious phase disconnection, greater energy being required for the detachment of the fibers and development of cracks.

- All of the mortar mixes with added fibers produce higher energy absorption values on compression than the reference mortars. This increase is gradual up to an addition of $1 \%$, irrespective of the fiber type used.

This research shows the technical feasibility of hydraulic lime mortars with carbon fibers, proving better performance than mortars with glass and basalt fibers. While it is true that no significant differences have been found in the pre-cracking behavior, a better post-cracking behavior of the mortars with carbon fibers can be observed, absorbing these types of mortars a greater amount of energy before the collapse.

\section{ACKNOWLEDGEMENTS}

The authors would like to thank the Proiescon chair for the partial financing of this work and the UPM School of Building Construction and Architecture for the availability of the materials laboratories for the performance of this work.

\section{REFERENCES}

1. Moropoulou, A.; Bakolas, A.; Moundoulas, P.; Aggelakopoulou, E.; Anagnostopoulou, S. (2013) Optimization of compatible restoration mortars for the earthquake protection of Hagia Sophia. J. Cult. Herit. 14 [3], e147-e152. https://doi.org/10.1016/j.culher.2013.01.008.

2. Bianco, N.; Calia, A.; Denotarpietro, G.; Negro, P. (2013) Laboratory assessment of the performance of new hydraulic mortars for restoration. Procedia Chem. 8, 20-27. https://doi.org/10.1016/j.proche.2013.03.004.

3. Arizzi, A.; Martínez- Huerga, G.; Sebastian-Pardo, E.; Cultrone, G. (2015) Mineralogical, textural and physicalmechanical study of hydraulic lime mortars cured under 
different moisture conditions. Mater. Construcc. 65 [318], e053. https://doi.org/10.3989/mc.2015.03514.

4. Gullota, D.; Goidanich, S.; Tedeschi, C.; Nijland, T.G.; Toniolo, L. (2013) Commercial NHL-containing mortars for the preservation of historical architecture. Part 1: Compositional and mechanical characterisation. Constr. Build. Mat. 38, 31-42. https://doi.org/10.1016/j. conbuildmat.2012.08.029.

5. Kozlovcev, P.; Přikryl, R. (2015) Devonian micritic limestones used in the historic production of Prague hydraulic lime ('pasta di Praga'): characterization of the raw material and experimental laboratory burning. Mater. Construcc. 65 [319], e060. https://doi.org/10.3989/mc.2015.06314.

6. Arizzi, A.; Viles, H.; Cultrone, G. (2012) Experimental testing of the durability of lime-based mortars used for rendering historic buildings. Constr. Build. Mat. 28 [1], 807-818. https://doi.org/10.1016/j.conbuildmat.2011.10.059

7. Tassew, S.T.; Lubell, A.S. (2014) Mechanical properties of glass fiber reinforced ceramic concrete. Constr. Build. Mat. 51, 215-224. https://doi.org/10.1016/j. conbuildmat.2013.10.046.

8. Kizilkanat, A.B.; Kabay, N.; Akyüncü, V.; Chowdhury, S.; Akça, A.H. (2015) Mechanical properties and fracture behavior of basalt and glass fiber reinforced concrete: An experimental study. Constr. Build. Mat. 100, 218-224. https://doi.org/10.1016/j.conbuildmat.2015.10.006.

9. Fenu, L.; Forni, D.; Cadoni, E. (2016) Dynamic behaviour of cement mortars reinforced with glass and basalt fibres. Comp. Part B: Eng. 92, 142-150. https://doi. org/10.1016/j.compositesb.2016.02.035.

10. Lipatov, Y.V.; Gutnikov, S.I.; Manylov, M.S.; Zhukovskaya, E.S.; Lazoryak, B.I. (2015) High alkali-resistant basalt fiber for reinforcing concrete. Mater. Des. 73, 60-66. https://doi.org/10.1016/j.matdes.2015.02.022.

11. Kabay, N. (2014) Abrasion resistance and fracture energy of concretes with basalt fiber. Constr. Build. Mat. 50, 95-101. https://doi.org/10.1016/j.conbuildmat. 2013.09.040.

12. Graham, R.K.; Huang, B.; Shu, X.; Burdette, E.G. (2013) Laboratory evaluation of tensile strength and energy absorbing properties of cement mortar reinforced with micro-and meso-sized carbon fibers. Constr. Build. Mat. 44, 751-756. https://doi.org/10.1016/j.conbuildmat.2013.03.071.

13. Shu, X.; Graham, R.K.; Huang, B.; Burdette, E.G. (2015) Hybrid effects of carbon fibers on mechanical properties of Portland cement mortar. Mater. Des. 65, 1222-1228. https://doi.org/10.1016/j.matdes.2014.10.015.

14. Nguyen, H.; Carvelli, V.; Fujii, T.; Okubo, K. (2016) Cement mortar reinforced with reclaimed carbon fibres, CFRP waste or prepreg carbon waste. Constr. Build. Mat. 126, 321-331. https://doi.org/10.1016/j.conbuildmat.2016.09.044.

15. Lucolano, F.; Liguori, B.; Colella, C. (2013) Fibre-reinforced lime-based mortars: A possible resource for ancient masonry restoration. Constr. Build. Mat. 38, 785-789. https://doi.org/10.1016/j.conbuildmat.2012.09.050.

16. Santarelli, M.L.; Sbardella, F.; Zuena, M.; Tirillò, J.; Sarasini, F. (2014) Basalt fiber reinforced natural hydraulic lime mortars: A potential bio-based material for restoration. Mater. Des. 63, 398-406. https://doi.org/10.1016/j. matdes.2014.06.041.

17. Arslan, M.E. (2016) Effects of basalt and glass chopped fibers addition on fracture energy and mechanical properties of ordinary concrete: CMOD measurement. Constr. Build. Mat. 114, 383-391. https://doi.org/10.1016/j. conbuildmat.2016.03.176.

18. EN 459-1 (2015) Building lime - Part 1: Definitions, specifications and conformity criteria. European Committee for Standardization. Retrieved from https://standards. iteh.ai/catalog/standards/cen/588081 bb-ff4e-4421-997c2d7dcab1b6ac/en-459-1-2015.

19. EN 196-1 (2016). Methods of testing cement - Part 1: Determination of strength. European Committee for Standardization. Retrieved from https://standards.iteh. ai/catalog/standards/cen/37b8816e-4085-4dcc-a642a383d9bddd6c/en-196-1-2016.
20. Gao, J.; Wang, Z.; Zhang, T.; Zhou, L. (2017) Dispersion of carbon fibers in cement-based composites with different mixing methods. Constr. Build. Mat. 134, 220-227. https://doi.org/10.1016/j.conbuildmat.2016.12.047.

21. EN 459-2 (2010) Building lime - Part 2: Test Methods. European Committee for Standardization. Retrieved from https://standards.iteh.ai/catalog/standards/cen/7e034aeda672-467a-8b6c-53c5d4f79a72/en-459-2-2010.

22. EN1015-3/A2(2006) Methods of testformortarformasonryPart 3: Determination of consistence of fresh mortar (by flow table). Retrieved from https://standards.iteh.ai/catalog/ standards/cen/fb7a5bb4-d8e4-4c91-a7f8-a5cc646ce3e9/ en-1015-3-1999-a2-2006.

23. EN 1015-6/A1 (2006) Methods of test for mortar for masonry - Part 6: Determination of bulk density of fresh mortar. Retrieved from https://standards.iteh.ai/catalog/ standards/cen/529d9f7a-4b23-4747-8e12-a3185038cb1e/ en-1015-6-1998-a1-2006.

24. EN 1015-10/A1 (2006) Methods of test for mortar for masonry - Part 10: Determination of dry bulk density of hardened mortar. European Committeefor Standardization. Retrieved from https://standards.iteh.ai/catalog/standards/cen/865ded6d-f5e0-43ba-9ba9-69da5400168a/ en-1015-10-1999-a1-2006.

25. EN 1015-7 (1998) Methods of test for mortar for masonry - Part 7: determination of air content of fresh mortar. Retrieved from https://standards.iteh.ai/catalog/standards/cen/3c66138f-1eb7-41a2-99c6-92ed26a7bdd1/ en-1015-7-1998.

26. EN 1015-11/A1 (2006) Methods of test for mortar for masonry - Part 11: Determination of flexural and compressive strength of hardened mortar. European Committee for Standardization. Retrieved from https://standards. iteh.ai/catalog/standards/cen/251 c5fb4-ef60-4285-9039be39d56242d3/en-1015-11-1999-a1-2006.

27. ASTM C1609/C1609M-12 (2012) Standard Test Method for Flexural Performance of Fiber-Reinforced Concrete (Using Beam with Third-Point Loading), ASTM International, West Conshohocken, PA. https://doi.org/ 10.1520/C1609 C1609M-12.

28. Hou, L.J.; Xu, S.L.; Zhang, X.F. (2012) Toughness evaluation of ultra-high toughness cementitious composite specimens with different depths. Mag. Concr. Res. 64 [12], 1079-1088. https://doi.org/10.1680/macr.11. 00186.

29. Li, Y.; Li, Y.; Shi, T.; Li, J. (2015) Experimental study on mechanical properties and fracture toughness of magnesium phosphate cement. Constr. Build. Mat. 96, 346-352. https://doi.org/10.1016/j.conbuildmat.2015.08.012

30. UNE 83508 (2004) Concrete with fibers. Determination of the index of tenacity in compression. Spanish Association for Standardization and Certification. Retrieved from https://www.aenor.com/normas-y-libros/ buscador-de-normas/une/?c=N0032568.

31. García-Cuadrado, J.; Rodríguez, A.; Cuesta, I. I.; Calderón, V.; Gutiérrez-González, S. (2017) Study and analysis by means of surface response to fracture behavior in lime-cement mortars fabricated with steelmaking slags. Constr. Build. Mat. 138, 204-213. https://doi.org/10.1016/j. conbuildmat.2017.01.122.

32. Jiang, C.; Fan, K.; Wu, F.; Chen, D. (2014) Experimental study on the mechanical properties and microstructure of chopped basalt fibre reinforced concrete. Mater. Des. 58, 187-193. https://doi.org/10.1016/j.matdes.2014.01.056.

33. Khushnood, R.A.; Muhammad, S.; Ahmad, S.; Tulliani, J.M.; Qamar, M.U.; Ullah, Q. Maqsom, A. (2018) Theoretical and experimental analysis of multifunctional high performance cement mortar matrices reinforced with varying lengths of carbon fibers. Mater. Construcc. 68 [332], e172. https://doi.org/10.3989/mc.2018.09617.

34. Pereira-de-Oliveira, L.A. Castro-Gomes, J.P.; Nepomuceno, M.C. (2012) Effect of acrylic fibres geometry on physical, mechanical and durability properties of cement mortars. Constr. Build. Mat. 27 [1], 189-196. https://doi.org/10.1016/j.conbuildmat.2011.07.061. 
Influence of the addition of carbon fibers on the properties of hydraulic lime mortars: comparison with glass and basalt fibers $\bullet 13$

35. Bustos-García, A.; Moreno-Fernández, E.; Zavalis, R. Valivonis, J. (2019) Diagonal compression tests on masonry wallets coated with mortars reinforced with glass fibers. Mater. Struct. 52 [3], 60. https://doi.org/10.1617/ s11527-019-1360-y.

36. Asprone, D.; Cadoni, E.; Lucolano, F.; Prota, A. (2014) Analysis of the strain-rate behavior of a basalt fiber reinforced natural hydraulic mortar. Cem. Concr. Compos. 53, 52-58. https://doi.org/10.1016/j.cemconcomp.2014.06.009.
37. Izaguirre, A.; Lanas, J.; Alvarez, J.I. (2011) Effect of a polypropylene fibre on the behaviour of aerial lime-based mortars. Constr. Build. Mat. 25 [2], 992-1000. https://doi. org/10.1016/j.conbuildmat.2010.06.080.

38. Serrano, R.; Cobo, A.; Prieto, M.I.; de las Nieves González, M. (2016) Analysis of fire resistance of concrete with polypropylene or steel fibers. Constr. Build. Mat. 122, 302-309. https://doi.org/10.1016/j.conbuildmat. 2016.06 .055 